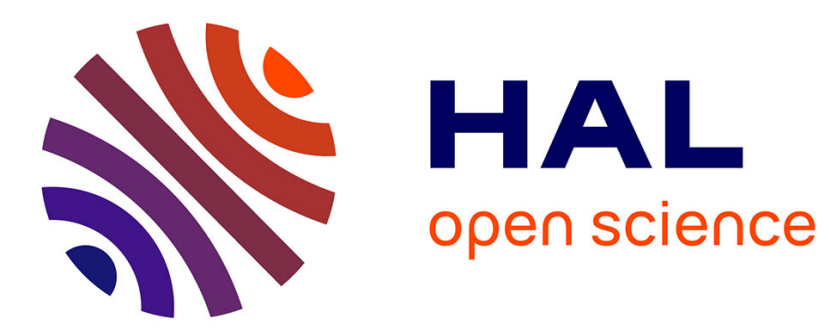

\title{
The determinants of electronic traceability adoption: a firm-level analysis of French agribusiness
}

Danielle Galliano, Luis Orozco

\section{To cite this version:}

Danielle Galliano, Luis Orozco. The determinants of electronic traceability adoption: a firm-level analysis of French agribusiness. Agribusiness, 2011, 27 (3), pp.379-397. 10.1002/agr.20272 . halshs01228086

\section{HAL Id: halshs-01228086 \\ https://shs.hal.science/halshs-01228086}

Submitted on 18 Dec 2015

HAL is a multi-disciplinary open access archive for the deposit and dissemination of scientific research documents, whether they are published or not. The documents may come from teaching and research institutions in France or abroad, or from public or private research centers.
L'archive ouverte pluridisciplinaire HAL, est destinée au dépôt et à la diffusion de documents scientifiques de niveau recherche, publiés ou non, émanant des établissements d'enseignement et de recherche français ou étrangers, des laboratoires publics ou privés. 


\title{
The determinants of electronic traceability adoption: a firm-level analysis
}

\section{of French agribusiness}

\author{
Danielle Galliano \\ French National Institute for Agricultural Research (INRA), UMR 1248 AGIR \\ Castanet Tolosan, France \\ E-mail: galliano@toulouse.inra.fr

\section{Luis Orozco} \\ Université de Toulouse, LEREPS \\ Toulouse, France \\ E-mail: luis.orozco@univ-tlse2.fr (Corresponding author)
}

\begin{abstract}
This paper aims to understand what factors influence firms to adopt electronic traceability systems (ETS) and notably the respective effects of the firm's internal characteristics, its vertical relations and its external environment. Traceability systems based on information and communication technologies (ICT) allow firms to collect, track, stock and transfer information on a range of product attributes. This study contributes to further understand traceability adoption by applying ICT adoption models to the case of ETS, and by using an original dataset, the 2002 ICT Survey, representative of all French agribusiness. The results suggest that a firm's degree of complexity (growing size, belonging to a group) and the development of its information system play a significant role in its adoption behavior. Moreover, they show that ETS adoption is more driven by a firm's narrow relations with specialized suppliers and downstream processors than by retailers [EconLit Classification: O330 Q130].
\end{abstract}

This is the peer reviewed version of the following article: [Galliano, D., Orozco, L., 2011. The determinants of electronic traceability adoption: a firm-level analysis of French agribusiness. Agribusiness 27, 379-397], which has been published in final form at [doi:10.1002/agr.20272]. This article may be used for non-commercial purposes in accordance with Wiley Terms and Conditions for Self-Archiving. 


\section{INTRODUCTION}

In recent years, the adoption of traceability systems has become a priority for firms throughout most supply chains in manufacturing sectors. This trend is particularly present in the agro-food sector, which is characterized by an ongoing need for firms to guarantee food quality and safety, in order to comply with contractual engagements, regulations, and consumers' demands. From the BSE (or Mad Cow Disease) crisis to recent food incidents, such as the salmonella scare on peanut products in the U.S. and Canada in 2009, the need for traceability systems has caught the attention of policy makers and food companies in most countries, even if specific practices and policies are usually adapted to national contexts.

While in the U.S., traceability systems have been promoted through private incentives (Golan et al., 2004), in Europe, agribusinesses must comply with EU regulation on the control and assurance of quality and safety, which include traceability ${ }^{1}$. The notion of traceability, as defined by the ISO Norm $9001: 2000$, is the "ability to trace the history, application or location" of what is being traced. In the context of the agro-food sector, and as defined by the General Food Law, traceability is the "ability to trace and follow a food, feed, food-producing animal or substance intended to be, or expected to be incorporated into a food or feed, through all stages of production, processing, and distribution" (European Parliament and Council, 2002). Traceability systems are thus conceived as a risk management tool to reduce the impact of product recalls and food safety incidents.

The "nature" of such systems, however, depends on the voluntary decision of operators to implement them, and we could consider that the adoption of an electronic traceability system (ETS) is a result of an economic calculation of firms. Therefore, the objective of this paper is to analyze, at the firm level, the determinants of the adoption of an ETS. An electronic traceability system can be defined as a complex combination of technical codification

\footnotetext{
${ }^{1}$ The General Food Law (Regulation EC 178/2002) requires basic "step-by-step" traceability from January $1^{\text {st }}$
} 
supports (commonly associated with bar-codes and electronic RFID tags) that, when coupled with ICT, allow firms to collect, track, stock, and transfer information on a range of product attributes $^{2}$.

The economic literature on traceability adoption has mainly focused on its drivers, the interoperability of systems along supply chains, and the economic implications (Buhr, 2003; Hobbs, 2004; Meuwissen et. al, 2003; Souza-Monteiro \& Caswell, 2010). Our objective is to further deepen this literature, first by focusing on the adoption determinants at firm level, second, by testing these determinants on a representative sample of firms, which to our knowledge has been rarely done before. More precisely, from a theoretical point of view, this paper aims to explain the adoption process by applying ICT adoption models to the case of electronic traceability systems. The main research hypothesis is that the adoption of electronic traceability depends on the combination of a firm's internal characteristics, its vertical relations (upstream and downstream) and the characteristics of its environment. From an empirical point of view, the objective is to test these hypotheses using an original dataset, the 2002 ICT Survey, carried out by the French National Institutes of Statistics, which provides individual information on a sample of firms, representative of the entire French agro-food sector.

The paper is structured as follows. Section 2 introduces the theoretical framework of the ICT adoption models, the explanatory factors, and the research hypothesis. Section 3 describes the dataset, the model and the variables used. Empirical findings are presented in Section 4. The last section concludes the paper and discusses the contributions.

\footnotetext{
${ }^{2}$ While the main focus of this paper is electronic traceability, the assumption is that certain companies assure some level of traceability using paper documents. For example, firms working in animal supply chains can register operations made to a product batch (its nature, composition, etc.) using their breed registries. This information can be transmitted using paper documents such as order forms, invoices, customs documents, etc., to clients, as long as they indicate at least the date of the transaction, the name and address of the suppliers, and the nature of the product. Introducing electronic traceability alleviates the ill effects of manual processes and eliminates transaction errors and labor intervention, while increasing the speed of product and inventory accuracy (Chryssochoidis et al., 2008). However, the initial investment costs involved in moving from paperbased to electronic systems are often high (Setboonsarng et al. 2009).
} 


\section{THEORETICAL BACKGROUND}

No matter how relevant traceability systems have become in the food industry, empirical studies on firm's and supply chain's adoption of them remain limited. The literature on technology adoption provides a framework to understand how firms behave with regard to a novel technology, regardless of the specificities of such technology. The following sections survey three models of technology adoption that are commonly used to explain ICT adoption (2.1) and the explanatory factor of electronic traceability adoption (2.2).

\subsection{The adoption models}

The innovation literature proposes several models that explain the diffusion of technologies (Geroski, 2000). This paper considers three groups of models (referred to as "equilibrium" models, "network externalities" models and "epidemic" models) that are commonly used to explain ICT adoption. The first group, consisting of the so-called “equilibrium” models (Battisti \& Stoneman, 2003; Karshenas \& Stoneman, 1993), considers the decision to adopt as the result of a cost-benefit calculation by potential adopters (firms), who anticipate the net benefits from adopting and using these technologies. These models are based on the hypothesis that information about the technology is known and shared and that the difference in the adoption levels between agents results from their heterogeneity. The expected benefits from the technology will depend on the firms" "rank effects" ${ }^{3}$. These effects suggest that firms differ in their own internal characteristics (size, access to financial resources, governance structure, market power, etc.). Depending on these effects, some firms

\footnotetext{
${ }^{3}$ The term "rank" is used because in these models the net benefits can be classified according to the type of firm. The firms positioned in the higher ranks will be the first to adopt the technology. Karshenas and Stoneman (1993) consider as well the existence of "order effects" and "stock effects" (not discussed in this paper), in which the benefits of the adoption depend on the position of the agent in the adoption order. These models take into account the behaviour of the competition, supposing that earlier adopters will obtain greater returns due to firstmover advantages (Fudenberg \& Tirole, 1985).
} 
will generate higher net benefits than others from the adoption of technologies. As noted by several authors, the choices and the performance of the technology will depend on the compatibility of this technology with the firm's goals and on its coherence with its organizational structure (Milgrom and Roberts, 1990). The decision to adopt ICT or traceability technologies might then require complementary organizational innovations (Bocquet et al., 2007; Greenan, 2003).

Second, technology adoption models with "network externalities" have been well studied in the literature, especially for competing technologies (David, 1985; Farrell \& Saloner, 1985; Katz \& Shapiro, 1986). Technology is characterized by network externalities that occur when the benefit an agent obtains from his adhesion to a network is positively correlated to the number of members connected to this network. In the same matter, it may be optimal for a firm to adopt a technology, simply because others have already done so, regardless of the information they have on the efficiency of such technology (Arthur, 1989). Facing two type of technologies, the incentive for one technology (A) falls as the diffusion of the second technology (B) proceeds and such an effect will be stronger "the more important are the network externalities and the more marginal is the technical difference" between B and A (Geroski, 2000, p.619).

Third, "epidemic" models (Mansfield, 1961) emphasize the influence of information spillover effects on the diffusion of technologies. A greater number of adopters indicates a greater amount of information that is available about the technologies and a higher diffusion rate. The basic hypothesis is that it takes time for information about a new technology to reach all potential users (Geroski, 2000). A potential user becomes a user through contact with an existing adopter; a greater number of adopters leads to a higher probability that a non-adopter will be in contact with an adopter and a higher probability that the non-adopter will be "contaminated". The assumption is that a new technology requires both the existence of a 
common source of information and a transmission process via "word to mouth". An implicit hypothesis underlying these epidemic models (and this is also one of their limitations) is that once individuals know of the technology, they will use it ${ }^{4}$.

Several authors have combined different adoption models taking into account the rank effects related to the firm's characteristics and the epidemic effects (Battisti and Stoneman, 2003; Galliano and Roux, 2008), in order to explain ICT adoption. The attempt of this contribution is to integrate the three approaches presented above and develop the following theoretical model.

First, we characterize the process of ETS adoption. We consider the discrete binary variable $d_{i}^{t}$ that takes value 1 if the firm possesses the new technology at time $t$ and 0 otherwise. At time $t$, a firm possesses the new technology if and only if the net benefit it has anticipated from its adoption in relation to its non-adoption is positive.

The expected net benefit of the adoption noted $\theta\left(x_{i}^{t}\right)$ is a function of the firm's specific characteristics (rank effects). Networks effects or increasing returns to adoption are noted $g\left(n e_{i}^{t}\right)$ : the adoption of the ETS by partners should generate stronger incentives for firms to adopt this new technology. More generally, the benefits of adopting this technology will depend on the number of other firms adopting the same technology. An additional hypothesis is made: spillover effects influence the firm's decision to adopt the new technology. Indeed, the adoption of the new technology by other firms in the same sector or the same geographical area generates information spillovers that may lead the firm to adopt this new technology in so far as these spillovers reduce the uncertainty concerning its characteristics. These epidemic effects are denoted $f\left(e e_{i}^{t}\right)$.

\footnotetext{
4 A similar approach, not discussed in this article, is the so-called "informational cascades" models, which assume that some adopters will choose a "wait and see" attitude, making the same choices as early adopters. In other words, firms follow an "observational learning" process, that is, a process in which agents decide based on both their own private and probabilistic informational signals, and the aggregate actions of predecessors facing a similar decision problem (Bikhchandani et al., 1998).
} 
Overall we consider that firm $i$ possesses the new technology $n$ at time $t$, i.e. $d_{i}^{n, t}=1$, if the subjective expected net benefit (in relation to non-adoption) is positive. It is defined as follows:

$\pi\left(x_{i}^{n, t}, n e_{i}^{n, t}, e e_{i}^{n, t}\right)=\theta\left(x_{i}^{n, t}\right)+g\left(n e_{i}^{n, t}\right)+f\left(e e_{i}^{n, t}\right)$

The first term represents the net benefits anticipated by a firm; the second term takes into account the adoption behaviors of other firms, thus the network effects, while the third accounts for the existence of information spillovers about the technology's characteristics, namely the epidemic effects. Note that a firm can choose to adopt the new technology, even if the first term (the expected returns) is negative, if the second and/or third term compensate for this.

\subsection{The explanatory factors}

In this section we attempt to determine the factors that are likely to influence the process of the adoption of electronic traceability, in accordance with the models described above. Based on the empirical literature in both ICT and traceability adoption ${ }^{5}$, three sets of factors has been highlighted: the firms' internal characteristics, the vertical network relations, and the characteristics of its environment.

\subsubsection{Internal characteristics of the firm}

Firms have different characteristics that influence their adoption behavior. According to the "rank models" view, large firms are described as having greater access to financial

\footnotetext{
${ }^{5}$ Variables on "consumer's demands" for traceability are not discussed in this paper given our firm-level approach and the nature of our data. However, several empirical studies have treated the matter (Dickinson and Bailey, 2002; Sans et al., 2008; Verbeke and Ward, 2006).
} 
resources, benefiting from economies of scale and scope, having a diverse workforce in terms of skills, having better access to information and being less risk averse with regard to adopting new technologies. These characteristics can be divided into structural characteristics, related to economies of scale (size) and scope (group belonging, multi-unit firm and brand image), and second, to the firm's information systems.

In the first group, most studies have found a positive relationship between ICT adoption and the size of the firm (Baldwin et al., 2004; Galliano et al., 2001; Karshenas and Stoneman, 1993; Mansfield, 1968). Similarly, the use of ICT to support and facilitate the practical implementation of traceability systems is a priori associated with larger firms (Pinto et al., 2006). Even if this relationship is not always a linear one, traceability systems tend to be adapted to the firm's size and complexity. Moreover, firms with superior financial resources and human capabilities are more likely to have a budget exclusively dedicated to traceability (Alfaro \& Rábade, 2009).

H1. Firm size is positively related to the adoption of an electronic traceability system.

In the same manner, belonging to a group reinforces the greater resources view, but it suggests a need for greater coordination between the units of the group and their traceability systems, especially if they offer the same type of product. This effect is rarely tested in the literature. Moreover, a multi-unit organizational form, where production units are located across different locations, is usually associated with higher costs of communication and coordination between them, which increase the likelihood of ICT adoption (Fischer and Johansson, 1994; Galliano et al., 2001). These costs are likely to increase similarly to the need for traceability. 
H2. Firms with multiple production units or belonging to a group are more likely to adopt an electronic traceability system.

The food safety literature emphasizes that one of the main reasons for implementing traceability systems is to reassure consumers about quality and safety. The costs of new products are high because of marketing expenditures, and advertising is the most widely used tool to inform both customers and final consumers about food quality and safety (Verbeke, 2005). The importance given by the firm to its brand image can be a strategic determinant of the firm's electronic traceability adoption, as firms are believed to take all necessary measures to maintain a good image and reputation.

H3. The importance firms give to their image is positively related to their adoption of electronic traceability

A second group of factors related to the firm's internal characteristic concern its information system. The firm's set of information and communication technologies can be conceived as an indicator of its information system and management choice as well as its degree of formalization and codification of knowledge. As noted in Steinmueller (2000), ICT investments allow for the "creation of individual and organizational memory, the reproduction of successful practices across organizational units, and the reconstruction of knowledge exploration and discovery" (p.262).

The costs of implementing electronic traceability systems include those associated with the adoption of the ICT necessary for its implementation, such as hardware, software package, communication technologies, training, etc. (Chryssochoidis et al., 2008; Setboonsarng et al., 2009). These costs will be lowered if the firm already has a sufficient stock of ICT and 
competencies to adopt the new technology. Different ICTs, especially e-business applications (Falk, 2005), such as Enterprise Resource Planning (ERP), indicate the nature of the firm's information system, on which electronic traceability systems will find support. The general view is that these applications should structure the firm's internal and external flow of traceability information. The idea is that the costs of adopting electronic traceability will be lower for those firms already using such applications.

The economic literature has shown how these technologies complement each other (Bocquet et al., 2007; Milgrom and Roberts, 1990), which, in the case of traceability systems, have been studied in recent years (ACTA-ACTIA, 2007; Van der Vorst et al., 2005). In France, ACTA-ACTIA (2007) identifies ERP as one of the main e-business applications used for the management of traceability data within firms. ERP consists of a "software package that uses database technology to control and integrate all the information related to a company's business (functions) including customer, supplier, product, employee and financial data" (Falk, 2005, p.1231).

Traceability systems are assumed to have local specificities for each firm, especially in terms of internal information and knowledge management. However, in order to compensate for such specificities, an external coordination with partners upstream and downstream is needed to assure the correct transmission of information. The ability to transfer the required information, in order to maintain the traceability of product batches, requires firms to have internal traceability procedures in place. Sending the necessary information requires a data formatting process (following the receiver's specifications) and can be sent either to a central web server (and thus available to different stakeholders) or directly to a receiver. The latter method comprises traditional e-mail, Extranet, other Internet-based exchange systems, or standard EDI (Electronic Data Interchange) formats. In the business-to-business context, EDI has been developed as a standard coordination tool (Brousseau, 1994), given its reliable 
means for achieving electronic, computer-to-computer information exchange (Bechini et al., $2008)^{6}$

H4. Firms with greater use of e-business applications are more likely to adopt electronic traceability.

\subsubsection{Vertical network relations}

Traceability involves the coordination of different operators in the supply chain. Several authors consider that the modes of coordination and network effects along supply chain operators are expected to be major determinants in the adoption of traceability (Banterle \& Stranieri, 2008; Charlier \& Valceschini, 2008; Souza-Monteiro \& Caswell, 2010).

Information technologies are tools used to facilitate the communication and coordination at the inter-firm level: higher monitoring and coordination costs are associated with higher expected returns from using ICT. Some authors show that the need to create and to maintain stable and collaborative relationships with partners increases the firm's probability of using ICT (Galliano et al., 2001). More precisely, sectoral and supply-chain effects can be explained in part by network externalities, meaning an increase in returns to the adoption of an electronic traceability system throughout the supply chain (Katz \& Shapiro, 1986). In this matter, Souza-Monteiro and Caswell (2010) show that vertical network effects occur when a decision taken by a third-tier firm downstream impacts the first-tier firms upstream in the cascade (in the case of contracts between the producer of a multi-ingredient product and its intermediate processors). The increased formalization of external relations into contractual

\footnotetext{
${ }^{6}$ EDI and Internet-based exchange systems can be two substitutable types of inter-organisational systems (Bakos, 1991), where the first carries greater sunk costs than the second. This is particularly relevant when firms have to manage "one-to-many" or "many-to-many" relations, because EDI system will be appropriate only when operating between two or very few companies (Bocquet et al., 2007).
} 
forms has been particularly highlighted as a corollary element to the traceability relations within supply chains (Banterle \& Stranieri, 2008).

External partners, such as suppliers, can advise firms on their own experience of adoption and can provide technical support. Alfaro and Rabade (2009) show, using a case of a Spanish vegetable firm, that a high level of integration with suppliers can be crucial for implementing electronic traceability systems. In fact, the food industry has been historically considered to be "low-tech" and technological changes to be dependent on suppliers. However, such changes on the supply side are channeled in part through the changing vertical structure of the industry, in which large retailers are gaining much power vis-à-vis their processors (Von Tunzelmann \& Acha, 2005). Downstream actors play a role in these relations, because in order to avoid liability costs, they have greater incentives to monitor the traceability of their suppliers (Charlier \& Valceschini, 2008). Thus, individual firms cannot ensure the overall safety of the entire production chain. The collective reputation of stakeholders can be damaged due to the actions (or lack thereof) of a few operators, which negatively affects the others. For instance, products sold under a retailer's or another firm's brand will be subject to strict specific production requirements from producers.

H5. The adoption behavior of external partners influences the adoption behavior of firms. As this relationship becomes stronger, so does the influence on firms, especially when these relations are formalized in contracts and specifications.

\subsubsection{Characteristics of the environment}

The innovation literature has shown that both the internal capabilities of firms and their interactions with external sources of knowledge are complementary to their innovative performance (Cohen \& Levinthal 1990). These external sources are more likely to come from 
the firm's environment, which can be related to the industry sector, the market or spatial environments.

The influence of the firm's sector of activity on its adoption behavior can be related to the type of product (its technical characteristics and its life cycle) and to specific regulations in a particular industry. Information is going to be more or less standardized depending on the type of product. Traceability is intimately connected with the product's life cycle: product traceability "loses its meaning if it is not able to go along the whole life of a product, keeping track of changes and related information, from design phase to its disposal" (Terzi et al. 2007, p. 267).

The epidemic approach anticipates that a firm's propensity to adopt a new technology increases if the firm in question belongs to an economy or a sector in which a large proportion of firms already use the new technology (Hollenstein, 2004). In the agro-food industry, for instance, the type of product is going to condition how batches are created and identified, as well as the technologies used, in order to establish their traceability procedure. The meat sector has a long history of identifying and tracking animals. They are characterized by long and complex supply chains with a tendency towards integration. This sector has been particularly exposed to food safety scandals (such as the BSE crisis), which sparked consumer's pressure and demands concerning food safety. Moreover, regulation also intervened early on in this sector, establishing a system for the identification of bovine animals and the labeling of beef products (c.f. Regulation EC 820/97). The existence of previous regulation does not translate into a bias in the adoption process; it just implies that this sector started to invest in traceability systems earlier than the others, and thus have higher probability of adopting ETS. Different sectors have specific characteristics that shape their traceability systems. For instance, the fresh produce (fruits and vegetables) sector is 
characterized by the development towards retail integration and branding, with coordinated chains, certified suppliers and contractual relations with retailers (Codron et al., 2007).

H6. Firms operating in a sector that has been exposed to a food safety scandal and where a large number of firms have adopted electronic traceability, have a greater propensity to adopt the technology.

The competitive environment has been recognized as a driver of ICT adoption in the innovation literature (Battisti \& Stoneman, 2005; Galliano \& Roux, 2008; Hollenstein, 2004). This literature tends to show that a firm's innovation capacity and its pace of innovation depend on its position on the market (a firm that already has a large market share is more likely to have the required capacity), the nature of the innovation and the type of market structure (see Reinganum, 1989, for a survey). The conclusions of empirical studies concerning the effects of market structure are ambiguous and divergent. Karshenas and Stoneman (1993) find that the degree of industrial concentration (share of the first five firms) has no influence on ICT adoption. Hollenstein (2004) finds that competitive pressure (approximated by the proportion of exports in the turnover), has no effect once a certain level of export is reached and thus evidence a non-linear effect of the export rate.

Exports can also indicate the firm's internationalization activities. Empirical works on technological innovations have shown a positive relationship between exports and innovation (Braga \& Willmore, 1991; Kumar \& Saqib, 1996). In the case of the international food markets, there has been a considerable decrease in tariffs and quotas. However, non-tariff barriers, often associated with countries' exigencies in terms quality and food safety, remain very present. The increase of non-tariff barriers requires greater transparency and communication on product characteristics. The evolution of international trade in the food 
industry will relay, besides traditional factors (competitive advantage, costs, etc.) on less traditional factors such as food safety and traceability (Briz et al., 2007). In order to face different markets and different requirements for food safety, firms find it very helpful to implement electronic traceability systems (Alfaro and Rábade, 2009).

H7. The internationalization of a firm's activity increases the probability of its adopting electronic traceability systems.

The general view is that firms are also influenced by their spatial environment, especially in their capacity to innovate and to adopt new technologies. This is explained from the perspective of epidemic models (Mansfield, 1961) assuming that information spillovers about the technology are spread around the firm. The increasing returns to adoption are associated with agglomeration economies: that is, firms benefit from their proximity to other firms as a result of the contact frequency, cooperation and presence of a local labor market (Vicente \& Suire, 2007). The characteristics of the territory determine the intensity of communication between firms and the existing information externalities. The hypothesis, often found in the literature, is that urban agglomeration economies facilitate access to a variety of infrastructures and service activities (IT services, technology suppliers etc.), as well as to a qualified workforce, which favors the adoption of technologies by firms.

Galliano and Roux (2008) show that epidemic effects increase the intensity of ICT use by urban firms rather than that by rural firms. The relative scarcity of these factors in rural areas, together with a low technological level, could explain the delay in the adoption process of rural firms (Gale, 1998). Through a case study on vegetable firms from the Ebro Valley Region in Spain, Rabade and Alfaro (2006) find that traceability is better implemented when firms work with suppliers located in close proximity to their manufacturing plant. 
H8. Firms located in urban areas are more likely to benefit from urban agglomeration externalities, thus being more likely to adopt electronic traceability.

\section{DATA AND METHODS}

\subsection{Data}

The data used for the analysis come from the 2002 Information and Communication Technologies Survey, conducted by the French National Institutes of Statistics (Service des études et des statistiques industrielles [Ministry of Industry; SESSI], Service central des enquêtes et des études statistiques [Ministry of Agriculture; SCEES], and Institut national de la statistique et des études économiques [Ministry of Economy; INSEE]) for a sample representing the entire French industrial sector. The survey was carried by mail between the autumn of 2002 and early 2003 , with an overall response rate of $89 \%{ }^{7}$. The final sample used in this paper is composed of 871 firms that are representative of the firms in the entire French agro-food industry (around 2821 firms) with respect to size and sector; each firm in our final sample has 20 or more employees. The main goal of this survey was to determine the state of adoption and use of different ICT within French firms.

The rationale for using such survey in our paper lays on a key variable asking whether firms possess a "product traceability tool", which is defined in the survey as a "tool that makes it possible to determine, in real time, the origin, location and history of a product", depending upon "information technology mechanisms, such as bar codes, electronic tags, etc. and other type of product identification technologies". Considering this definition, the choice

\footnotetext{
${ }^{7}$ This rather high response rate is due to the fact that all French national surveys, carried by the different statistical services of French ministries, and under de surveillance of the CNIS (Centre National de l'Information Statistique) are mandatory. Firms are obliged by law to respond to the survey, otherwise be subjected to an administrative fine. Access to this data, however, is restricted to researchers having agreed to secrecy agreements.
} 
was made to use this variable as a proxy for the existence of an electronic traceability system in the firm ${ }^{8}$.

The survey data shows that $43.18 \%$ of firms in the agro-food sector have adopted an electronic traceability system. This gives an idea of the specificity systems in agro-food, if we compare to other sectors such as consumer goods (15.90\%), automobile (24.50\%), equipment goods (14.43\%) and intermediate goods (26.98\%).

The data was merged with the French Firm's Annual Survey (EAE) from 2001, also carried out by the French National Institutes of Statistics, which provides exhaustive information on the firms' activities, structural characteristics, number of production units, and location of their main office. The Financial Links (LIFI) Survey 2001 was used to complement information on whether the firms belong to a group or not.

\subsection{Estimation method}

The analysis of the existence of an electronic traceability system is carried out by the estimation of a binary Probit model, where the probability of adopting electronic traceability systems $(\mathrm{ETS}=1)$ is function of the firm's internal characteristics, the vertical relationships and the characteristics of its environment. Probit models are typically used to explaining a dichotomous dependent variable with empirical specifications in terms of a latent regression (Greene, 2003). For all estimations, we use weighted data, in order to correct for sampling bias (i.e., for ensuring a better representation of the individual firm's distribution) and provide results for the entire population. Electronic traceability adoption by firms depends on the characteristics of the firms, their vertical network effects and the effects of information

\footnotetext{
${ }^{8}$ The database covers a period in which traceability was in much discussion in France and in Europe. Even though traceability became mandatory on January $1^{\text {st }} 2005$ (through Regulation 178/2002), agribusinesses were already investing in traceability systems anticipating the policy requirements. For instance Regulation 820/97 on the identification of bovine animals and labeling of beef products was already in place, and the European Commission has published the White Paper on Food Safety in 2000, demanding food operators for the introduction of traceability.
} 
spillovers from their sectoral and local environment. From Equation (1), the probit equation is formally written as follows:

$$
\pi_{i}=\beta w_{i}^{\prime}+\varepsilon_{i}=\beta_{1} x_{i}^{\prime}+\beta_{2} n e_{i}^{\prime}+\beta_{3} e e_{i}^{\prime}+\varepsilon_{i}
$$

Where $\beta$ is the vector of parameters, $x_{i}^{\prime}$ the vector of the firm's internal characteristics, $n e_{i}^{\prime}$ the vertical network effects, and $e e_{i}^{\prime}$ the epidemic effects; with $\varepsilon_{i} \rightarrow \mathrm{N}(0,1)$.

The observed discrete variable is $d_{i}=\left\{\begin{array}{l}1 \text { if } \pi_{i}^{*}>0 \\ 0 \text { otherwise }\end{array}\right.$.

Then, $\operatorname{Prob}\left(d_{i}=1 / w_{i}\right)=\Phi\left(\beta w_{i}^{\prime}\right)$ and $\operatorname{Prob}\left(d_{i}=1 / w_{i}\right)=\Phi\left(\beta w_{i}^{\prime}\right)$, where $\Phi($.$) is the$ standard cumulative normal.

\subsection{Variables}

\subsubsection{Dependent variable}

The dependent variable indicates whether a firm posses an electronic traceability system. This dichotomous variable equals 1 if the firm has adopted an ETS and 0 otherwise. This variable does not allow the measuring of intensity or a degree of traceability, an argument commonly claimed in the literature (See Souza-Monteiro and Caswell, 2010, for a survey ). Golan et al. (2004) set a framework considering that traceability depends on its breadth (amount of information recorded), depth (the different levels of the supply chain) and precision (detail to pinpoint a particular food product), and test it on several case studies. Pouliot and Sumner (2008) model a supply chain in which traceability is not a choice variable but a degree measured as the probability of identifying the specific source of contamination: however empirical applications are not given. Only Souza-Monteiro and Caswell (2009) use a dichotomous variable to estimate the choice between two possible contracts with different 
levels of traceability. For the purpose of this paper, the dichotomous dependent variable used allows for distinguishing between two populations (adopters and non-adopters) and associating the entire variables (see 3.3.2 below) necessary to construct the econometric model.

Descriptive statistics of the sample are presented in table 1. The third and fourth columns show the characteristics of firms having adopted an electronic traceability system (EST=1). By 2002, just over $43 \%$ of French firms belonging to the agro-food sector have adopted ETS. These firms seem to be characterized by being large firms with 250 employees or more (20.69\% of adopters, when they represent only $12.48 \%$ of French agribusiness), subsidiaries of a group (72.05\%), and equipped with ERP (57.47\%), EDI (74.58\%) and Intranet (51.35\%).

\section{[Insert table 1]}

\subsubsection{Independent variables}

The complete description of variables is shown in table 2 . Four variables are used in the model to characterize the structure of the firm (as part of its internal characteristics). The size of the firm is measured using the number of workers employed (Hollenstein, 2004; Galliano and Roux, 2008). Whether a firm belongs to a group indicates that firms have greater access to resources, even if this integration depends on the functional division and the level of centralization of decision-making within the group. The firm is considered to have a multiunit structure if it has two or more establishments carrying part of its activity. The advertising expenditures is used as a proxy for the importance a firm attaches to its brand image and is measured by the logarithm of advertisement expenses over total revenue. As mentioned in Lucchetti and Sterlacchini (2004), log transformations are usually taken in order to reduce data variance. 
[Insert table 2]

In order to capture the nature of the firm's information system, a series of e-business applications are introduced (on which electronic traceability systems are expected to find support). As data management applications concerns, four binary variables are introduced (ERP, DMS, Workflow and Data-warehouse), each equal to one if present in the firm and zero otherwise. A similar action was taken to test the use of communication technologies (EDI, Intranet and Extranet).

Using firm-level data has the inconvenient characteristic of not illustrating the links between the firms present in the sample or their positions along the supply chain. However, in order to provide and indicate the firm's upstream activities, the expenses in capacity subcontracting and specialized sub-contracting activities are introduced, assuming that specialized sub-contracting is accompanied by stricter specifications. In the same matter, two variables are used with regards to the firm's downstream activities: the firm's sales under a retailer's brand and the sales under another firm's brand. The former could indicate a greater dependency on retailers while the latter, a greater role of other downstream processors. In both cases, the assumption is made that the firm follows a set of specifications, quality requirements, etc.

In order to capture the epidemic effects we use variables from the firm's environment. The firm's main activity is used to distinguish between six sectors of activity (Meat, Prepared fruits and vegetables, Dairy, Processed animal feed, Other food products, and Beverages). In order to capture the firm's market environment, the $C 4$ market concentration ratio is used as an indicator of the level of competition in the sector. Then, the firm's rate of exports, a proxy of the firm's degree of openness to foreign markets, is introduced, differentiating between exports to the EU and outside the EU. With regards to the spatial environment, the head office 
location is retained in order to distinguish between four types of locations. The ZAUER zoning database ${ }^{9}$ is used to characterize the nature of the firms' geographical location (urban or rural). The obtained typology allows for the categorization of all French cities into seven spatial categories, which are then aggregated into four levels: urban zones, peri-urban zones, rural poles and rural isolated areas. In Appendix A, a correlation matrix is presents, which shows no severe multicollinearity between the explanatory variables. Special attention is given to the variables more than 500 (large firms), group and multi-unit, for which no high correlation is found.

\section{RESULTS}

Table 3 presents the estimates of the econometric model for electronic traceability adoption, organized into three categories of factors: the internal characteristics of the firms, their vertical relations and the characteristics of their environment. To a great extent, the results show, as expected, that these three categories of factors play a role, with different degrees and contrasted effects, in the ETS adoption process. They highlight the complexity of interactions and multiplicity of factors present in a traceability system.

[Insert table 3]

Concerning the internal characteristics, and more precisely the first hypothesis, the probability of adopting an electronic traceability system appears linearly correlated to the size of the firm. This result allows us to accept Hypothesis $1^{10}$. A larger firm has a greater need to adopt electronic traceability. Although this is not directly observed, it could also suggest that smaller firms rely on paper documents in order to assure some level of traceability. Moreover,

\footnotetext{
${ }^{9}$ That is the ZAUER file (Zonage en aires Urbaines et en Aires d'Emploi de l'espace Rural) from 1999, also provided by INSEE.

${ }^{10}$ Table 4 summarized all eight hypothesis and results
} 
while firms belonging to a group have a positive effect on the adoption of electronic traceability, those having multiple units do not. This negative effect is contrary to the expected result insofar as a multi-location structure implies important needs in terms of coordination, which is favorable to the intense use of ICT. Controlled by the size, this variable (multi-unit) tends to show a low technical division of labor between the firm's production units in agribusiness instead of a more functional division with fewer needs for traceability. Galliano and Roux (2008) show, in the case of rural firms, that this effect might be related to a reduction in information/coordination needs caused by the location of one of their units in an urban area. This result only allows us to partially accept Hypothesis 2, i.e. only belonging to a group plays a positive role in ETS adoption.

With regard to the brand image of the firm, the results show a non significant effect of advertisement expenditures on ETS adoption, and thus, any statement can be made about Hypothesis 3. Although, traceability systems are considered an effective tool to prevent the chances of potential recalls that could damage the firm's reputation (Kumar and Budin, 2006); traceability and advertisement are not substitutable in building the firm's image. This could suggest that advertisement can be considered as complementary to traceability; but do not have a direct influence on it. This result, rarely tested in the literature, can be considered an interesting area for further research, especially with regards to the literature on reputation effects.

With regard to the information systems, the probability of adopting an electronic traceability system clearly depends on a firm's stock and use of such technologies. This confirms Hypothesis 4 in that firms with other e-business applications have acquired the level of knowledge necessary to facilitate the adoption of new technologies such as electronic traceability systems. For instance, traceability can be integrated as a supplementary module to the firm's ERP, which will reduce the costs associated with the adoption. Document 
management systems (DMS), for which the results show a positive effect, are commonly use to process and store electronic documents, which is very useful for stocking and tracing them. In terms of communication technologies, the results confirm the descriptive statistics, in which firms using Intranet and EDI as communication technologies are more likely to have adopted electronic traceability systems. These results demonstrate the growing role of new technologies with regards to both the firm's internal efficiency and the building up of interfirm relations.

Concerning the firm's vertical relations, often highlighted in the literature as a key element, the results are particularly interesting because they indicate a different influence of downstream actors. Only the firm's sales under another firm's brand play a very positive and significant role on the adoption of electronic traceability, while the firm's sales under a retailer's brand does not. These results are consistent with Hypothesis 5, as they agree with the contractual literature on supply chain relations, suggesting that ETS adoption is linked to the compliance with clients' specifications. However, they show that the influence of downstream actors is not homogeneous. This would suggest that contractual relations and specifications from downstream processors are more constraining than those of retailers, which might be associated with less complex and more generic products.

Moreover, an important and significant positive effect is found for the influence of expenses in specialized subcontracting on the adoption probability. This practice relates to the fact that firms "makes-make" a certain activity to a sub-contractor, setting their own specifications. This tends to show that strong relations with suppliers, especially when they are formalized through contracts and specifications, positively influence the adoption of electronic traceability. This result is strengthened by the negative effect of capacity subcontracting, which unlike the former, does not rely a priori on product specifications, or any other specific relation with the supplier. 
Concerning the external environmental factors, the results suggest a larger influence of sector and spatial environment over those related to the market. The role of the meat sector throughout the historical process of traceability implementation is evidenced by the negative and significant results of the other five sectors compared to meat. This can be explained in part by both the effects of the BSE crisis and the fact that regulation in the meat industry was established earlier and with much more precision than it was in other sectors. Results indicate that when a large number of firms within a sector have adopted a technology there is a higher probability that a particular firm will adopt that technology. Hypothesis 6 is thus accepted.

The results show different roles played by the market environment. Only exports to nonEU countries seem to play a significant role, while market concentration and exports to the EU zone show no influence. This result can be interpreted as the need for multinational firms exporting outside EU borders to develop the necessary logistic systems in order to meet a diversity of non-tariff barriers. This result would require further research. A very first test of this result shows the more a firm exports outside the EU, the more it becomes likely to enter into competitive markets and belong to the beverages sector (a very controlled sector at the international level). These different aspects favor electronic traceability at the international level. Therefore, Hypothesis 7 is accepted.

With regard to the spatial environment, a peri-urban area or a rural pole is more favorable to adoption than urban areas are. This result leads us to reject Hypothesis 8, in which the technology adoption process is favored by information spillovers on the technology, characteristic of urban zones. This urban agglomeration effect is only verified for rural isolated areas, which remain disadvantaged in the access of traceability technologies. Being located in an isolated rural area has a negative influence on the decision to adopt electronic 
traceability. This result seems to be related to the low level of technological intensity of the products manufactured in rural areas and thus the low level of the skills needed to produce them (Gale, 1998). More generally, this also relates to the influence of information spillovers on innovation and technologies, which are missing from rural zones. In reference to other zones, the positive effect of a location in peri-urban zones and rural poles translates into a specificity of agribusiness, which presents a more disperse spatial organization across a territory, close to both production and consumption areas. Peri-urban zones and rural poles remain privileged zones for the location of intermediate processors, which favors the adoption.

\section{DISCUSSION AND CONCLUSIONS}

The aim of this paper was to apply ICT adoption models and concepts to the specific case of electronic traceability systems. The idea was to test these concepts, and to highlight the firms' adoption mechanisms in agro-food, a sector particularly concerned with traceability. These models take into consideration rank effects related to the characteristics of the firm, network externalities and epidemic effects. This framework, supported by an original French survey on ICT behaviors in the agro-food industry, allowed us to test three groups of factors in the process of electronic traceability adoption: the internal characteristics of the firm, its vertical network relations and the different characteristics of its environment.

The results show, at both the internal and external levels, the role played by the modes of coordination and information flows between actors, in the process of adopting electronic traceability systems. The originality of these systems resides in the fact that they cover both an organizational practice (that allows for coordination between supply chain operators) and a technology (a technical system for the tracking of products and the tracing of the related information). In this way, the results highlight that a firm's degree of complexity (growing 
size, belonging to a group, etc.) and the development of its information system play a significant role in its adoption behavior. Large firms, with access to greater resources, adopted electronic traceability before it became mandatory in the EU. These adopters are also characterized by having a stock of ICT and a more developed information system than those used by non-adopters.

At the external level, the results shows that a firm's formalized relations with downstream processors and specialized suppliers positively influence the adoption process. An interesting contribution of this paper is to show that, contrary to what the literature suggests ETS adoption seems to be more driven by these downstream processors than by retailers. Further empirical in-depth research could explain the influence of retailers and the evolution of their impacts on traceability adoption. Nevertheless, these results suggest that the technical and economic relations between actors in the supply chain are more important for ETS adoption, than their relation with retailers.

With regard to policy implications, the results suggest that electronic traceability adoption is mainly associated with large firms, with closer relations with downstream processors and specialized suppliers, and with the presence in international markets. Developing a better understanding of factors that influence electronic traceability adoption, this paper provides indications regarding the types of firms that could have difficulties in the adoption process. These are small firms, which make relatively little use e-business applications, are located in rural isolated areas, etc. These results can be useful for policy makers to provide the necessary adoption incentives for these firms. The research agenda could further explore the effects of organizational variables in the adoption process in order to determine which organizational forms are more suitable for the adoption of new technologies. It could also examine the future of traceability systems, which go beyond a risk management tool, to a way to market products with credence attributes. 


\section{APPENDIX}

\section{A. Correlation matrix of independent variables}

[Insert table A1]

\section{ACKNOWLEDGEMENTS}

The authors are very grateful to the participants at the $12^{\text {th }}$ EAAE Congress in Ghent for their helpful comments. This research was supported by the French National Institute for Agricultural Research and the French Midi Pyrenees Region (PSDR-COMPTER Project). The analysis and comments made here are however our sole responsibility.

\section{REFERENCES}

ACTA-ACTIA, (2007). Traçabilité: Guide pratique pour l'agriculture et l'industrie alimentaire 2 ed., Paris: ACTA-ACTIA.

Alfaro, J.A. \& Rábade, L.A., (2009). Traceability as a strategic tool to improve inventory management: A case study in the food industry. International Journal of Production Economics, 118, 104-110.

Arthur, W.B., (1989). Competing technologies, increasing returns, and lock-in by historical events. Economic Journal, 99, 116-131.

Bakos, J.Y., (1991). Information Links and Electronic Marketplaces: The Role of Interorganizational Information Systems in Vertical Markets. Journal of Management Information Systems, 8, 31-52.

Baldwin, J.R., Sabourin, D. \& Smith, D., (2004). Firm performance in the Canadian food processing sector: the interaction between ICT, advanced technology use and human resource competencies. In OCDE, (Ed.). The economic impact of ICT: measurement, evidence and implications (pp. 153-81). Paris.

Banterle, A. \& Stranieri, S., (2008). Information, labelling, and vertical coordination: an analysis of the Italian meat supply networks. Agribusiness, 24, 320-331.

Battisti, G. \& Stoneman, P., (2003). Inter-and intra-firm effects in the diffusion of new process technology. Research Policy, 32, 1641-1655.

Battisti, G. \& Stoneman, P., (2005). The intra-firm diffusion of new process technologies. International Journal of Industrial Organization, 23, 1-22. 
Bechini, A., Cimino, M., Marcelloni, F., Tomasi, A., (2008). Patterns and technologies for enabling supply chain traceability through collaborative e-business. Information and Software Technology, 50, 342-359.

Bikhchandani, S., Hirshleifer, D. \& Welch, I., (1998). Learning from the Behavior of Others: Conformity, Fads and Informational Cascades. Journal of Economic Perspectives, 12, 151-170.

Bocquet, R., Brossard, O. \& Sabatier, M., (2007). Complementarities in organizational design and the diffusion of information technologies: An empirical analysis. Research Policy, 36, 367-386.

Braga, H. \& Willmore, L., (1991). Technological imports and technological effort: an analysis of their determinants in Brazilian firms. The Journal of Industrial Economics, 39, 421432.

Briz, J., de Felipe, I. \& Garcia, M., (2007). Food Safety in International Trade: The Spanish experience in Mediterranean products. In M. Canavari, D. Regazzi, \& R. Spadoni, (Eds.). International Marketing and International Trade of Quality Food Products (pp. 605-621). Bologna: Avenue Media.

Brousseau, E., (1994). EDI and Inter-firm Relationships: Toward a Standardization of Coordination Processes. Information Economics and Policy, 6, 319-347.

Buhr, B.L., (2003). Traceability and Information Technology in the Meat Supply Chain: Implications for Firm Organization and Market Structure. Journal of Food Distribution Research, 34, 13-26.

Charlier, C. \& Valceschini, E., (2008). Coordination for traceability in the food chain. A critical appraisal of European regulation. European Journal of Law and Economics, 25, 115.

Chryssochoidis, G, Karagiannaki, A., Pramatari, K., Kehagia, O., (2008). A cost-benefit evaluation framework of an electronic-based traceability system. British Food Journal, $111,565-582$.

Codron, J., Fares, M. \& Rouviere, E., (2007). From Public to Private Safety Regulation? The Case of Negotiated Agreements in the French Fresh Produce Import Industry. International Journal of Agricultural Resources, Governance and Ecology, 6, 415-427.

Cohen, W.M. \& Levinthal, D.A., (1990). Absorptive Capacity: A New Perspective on Learning and Innovation. Administrative Science Quarterly, 35, 128-152.

David, P.A., (1985). Clio and the Economics of QWERTY. American Economic Review, 75, 332.

Dickinson, D.L. \& Bailey, D., (2002). Meat Traceability: Are U.S. Consumers Willing to Pay for It? Journal of Agricultural and Resource Economics, 27, 348-364. 
European Parliament and Council, (2002). Regulation (EC) No. 178/2002 of 28 January 2002 laying down the general principles and requirements of food law, establishing the European Food safety Authority and laying down procedures in matters of food safety. Official Journal of the European Union, 1-24.

Falk, M., (2005). ICT-linked firm reorganisation and productivity gains. Technovation, 25, 1229-1250.

Farrell, J. \& Saloner, G., (1985). Standardization, compatibility, and innovation. RAND Journal of Economics, 16, 70-83.

Fischer, M. \& Johansson, B., (1994). Networks for Process Innovation by Firms: Conjectures from Observations in Three Countries. In B. Johansson, C. Karlsson, \& L. Westin, (Eds.). Patterns of a Network Economy (pp. 261-272). Heidelberg: Springer-Verlag.

Fudenberg, D. \& Tirole, J., (1985). Preemption and Rent Equalization in the Adoption of New Technology. Review of Economic Studies, 52, 383-401.

Gale, H.F., (1998). Rural Manufacturing on the Crest of the Wave: A Count Data Analysis of Technology Use. American Journal of Agricultural Economics, 80, 347-359.

Galliano, D., Roux, P. \& Filippi, M., (2001). Organisational and spatial determinants of ICT adoption: the case of French industrial firms. Environment and Planning A, 33, 16431663.

Galliano, D. \& Roux, P., (2008). Organisational motives and spatial effects in Internet adoption and intensity of use: evidence from French industrial firms. The Annals of Regional Science, 42, 425-448.

Geroski, P.A., (2000). Models of technology diffusion. Research Policy, 29, 603-625.

Golan, E., Krissoff, B., Kuchler, F., Nelson, K., Price, G., \& Calvin, L., (2004). Traceability in the US Food Supply: Economic Theory and Industry Studies, (Agricultural Economic Report No. 830). Washington, DC: U.S. Department of Agriculture, Economic Research.

Greenan, N., (2003). Organisational change, technology, employment and skills: an empirical study of French manufacturing. Cambridge Journal of Economics, 27, 287-316.

Greene, W.H., (2003). Econometric Analysis (5th), Prentice Hall.

Hobbs, J.E., (2004). Information asymmetry and the role of traceability systems. Agribusiness, 20, 397-415.

Hollenstein, H., (2004). Determinants of the adoption of Information and Communication Technologies (ICT): An empirical analysis based on firm-level data for the Swiss business sector. Structural Change \& Economic Dynamics, 15, 315-342.

Karshenas, M. \& Stoneman, P.L., (1993). Rank, Stock, Order, and Epidemic Effects in the Diffusion of New Process Technologies: An Empirical Model. The RAND Journal of Economics, 24, 503-528. 
Katz, M.L. \& Shapiro, C., (1986). Technology Adoption in the Presence of Network Externalities. Journal of Political Economy, 94, 822-841.

Kumar, N. \& Saqib, M., (1996). Firm size, opportunities for adaptation and in-house R \& D activity in developing countries: the case of Indian manufacturing. Research Policy, 25, 713-722.

Kumar, S. \& Budin, E.M., (2006). Prevention and management of product recalls in the processed food industry: a case study based on an exporter's perspective. Technovation, 26, 739-750.

Lucchetti, R. \& Sterlacchini, A., (2004). The Adoption of ICT among SMEs: Evidence from an Italian Survey. Small Business Economics, 23, 151-168.

Mansfield, E., (1968). Industrial Research and Technological Innovation: An Econometric Analysis, RS Means Company.

Mansfield, E., (1961). Technical change and the rate of imitation. Econometrica, 29, 741-766.

Meuwissen, M., Velthuis, A., Hogeveen, H., Huirne, R., (2003). Traceability and certification in meat supply chains. Journal of Agribusiness, 21, 167-181.

Milgrom, P. \& Roberts, J., (1990). The economics of modern manufacturing: Technology, Strategy and Organization. American Economic Review, 80, 511-528.

Pinto, D., Castro, I. \& Vicente, A., (2006). The use of TIC's as a managing tool for traceability in the food industry. Food Research International, 39, 772-781.

Pouliot, S. \& Sumner, D.A., (2008). Traceability, Liability, and Incentives for Food Safety and Quality. American Journal of Agricultural Economics, 90, 15-27.

Rabade, L.A. \& Alfaro, J.A., (2006). Buyer-supplier relationship's influence on traceability implementation in the vegetable industry. Journal of Purchasing and Supply Management, $12,39-50$.

Reinganum, J.F., (1989). The timing of innovation: Research, development, and diffusion. In R. Schmalensee \& R. Willig, (Eds.). Handbook of industrial organization (pp. 849-908). Amsterdam, The Netherlands: North-Holland.

Sans, P., de Fontguyon, G. \& Giraud, G., (2008). Value-based labels for fresh beef: an overview of French consumer behaviour in a BSE crises context. International Journal of Consumer Studies, 32, 407-413.

Setboonsarng, S., Sakai, J. \& Vancura, L., (2009). Food Safety and ICT Traceability Systems: Lessons from Japan for Developing Countries, (ADBI Working Paper Series $\mathrm{N}^{\circ} 139$ ). Tokyo: Asian Development Bank Institute. Available at: http://www.adbi.org. 
Souza-Monteiro, D.M. \& Caswell, J.A., (2009). Traceability adoption at the farm level: An empirical analysis of the Portuguese pear industry. Food Policy, 34, 94-101.

Souza-Monteiro, D.M. \& Caswell, J.A., (2010). The Economics of Voluntary Traceability in Multi-Ingredient Food Chains. Agribusiness, 26, 122-142.

Steinmueller, W., (2000). Will new information and communication technologies improve the 'codification' of knowledge? Industrial and Corporate Change, 9, 361-376.

Terzi, S., Panetto, H., Morel, G., \& Garetti, M., (2007). A holonic metamodel for product traceability in Product Lifecycle Management. International Journal of Product Lifecycle Management, 2, 253-289.

Van der Vorst, J., Beulens, J. \& Van Beek, P., (2005). Innovations in Logistics \& ICT in Food Supply Chain Networks. In W. Jongen \& M. Meulenberg, (Eds.). Innovation in Agri-Food Systems (pp. 245-292). Wageningen: Wageningen University Publishers.

Verbeke, W., (2005). Agriculture and the food industry in the information age. European Review of Agricultural Economics, 32, 347-368.

Verbeke, W. \& Ward, R.W., (2006). Consumer interest in information cues denoting quality, traceability and origin: An application of ordered probit models to beef labels. Food Quality and Preference, 17, 453-467.

Vicente, J. \& Suire, R., (2007). Informational Cascades versus Network Externalities in Locational Choice: Evidence of 'ICT Clusters' Formation and Stability. Regional Studies, 41, 173-184.

Von Tunzelmann, N. \& Acha, V., (2005). Innovation in 'low-tech'industries. In J. Fagerberg, D. Mowery, \& R. Nelson, (Eds.). The Oxford Handbook of Innovation (pp. 407-32). Oxford: Oxford University Press. 


\section{LIST OF TABLES}

Table 1: The characteristics of the sample

\begin{tabular}{|c|c|c|c|c|}
\hline & \multicolumn{2}{|c|}{ Total of agro-food firms } & \multicolumn{2}{|c|}{ ETS adopters } \\
\hline & Num. & $\%$ & Num. & $\%$ \\
\hline Total & 2821 & 100 & - & - \\
\hline ETS adopters & 1281 & 43.20 & 1281 & 100 \\
\hline \multicolumn{5}{|l|}{ Internal characteristics } \\
\hline \multicolumn{5}{|l|}{ Size } \\
\hline From 20 to $49^{\mathrm{a}}$ & 1267 & 44.91 & 407 & 33.41 \\
\hline From 50 to 249 & 1202 & 42.61 & 559 & 45.90 \\
\hline From 250 to 499 & 189 & 6.69 & 123 & 10.06 \\
\hline More than 500 & 163 & 5.79 & 130 & 10.63 \\
\hline Group & 1695 & 60.11 & 878 & 72.05 \\
\hline Multi-unit & 1141 & 40.44 & 528 & 43.36 \\
\hline ERP & 1373 & 48.67 & 700 & 57.47 \\
\hline DMS & 314 & 11.12 & 223 & 18.29 \\
\hline Workflow & 276 & 9.78 & 205 & 16.79 \\
\hline Data-warehouse & 397 & 14.09 & 284 & 23.31 \\
\hline EDI & 1779 & 63.08 & 909 & 74.58 \\
\hline Intranet & 1000 & 35.46 & 626 & 51.35 \\
\hline Extranet & 208 & 7.37 & 145 & 11.87 \\
\hline \multicolumn{5}{|c|}{ Characteristics of the environment } \\
\hline \multicolumn{5}{|l|}{ Sector of activity } \\
\hline Meat sector & 962 & 34.09 & 474 & 38.92 \\
\hline Prepared fruit and vegetables & 141 & 5.00 & 56 & 4.62 \\
\hline Dairy products & 296 & 10.48 & 129 & 10.59 \\
\hline Processed animal feed & 198 & 7.03 & 81 & 6.67 \\
\hline Other food products & 938 & 33.25 & 352 & 28.86 \\
\hline Beverages & 286 & 10.13 & 126 & 10.34 \\
\hline \multicolumn{5}{|l|}{ Main office location } \\
\hline Urban area & 1329 & 47.12 & 559 & 45.88 \\
\hline Peri-urban area & 572 & 20.26 & 274 & 22.49 \\
\hline Rural pole & 390 & 13.81 & 220 & 18.09 \\
\hline Rural isolated area & 530 & 18.80 & 165 & 13.54 \\
\hline
\end{tabular}

Source: EAE, LIFI and ICT Survey (2002), French National Institutes of Statistics. Authors' calculations. Weighted data

${ }^{a}$ The line show that 1267 firms in the sample (44.91\%) have 20 to 49 employees. They represent $33.41 \%$ of electronic traceability adopters. 
Table 2: Specifications of the explanatory variables

\begin{tabular}{|c|c|c|c|}
\hline Variables & Definition & Source & Expected sign \\
\hline \multicolumn{4}{|l|}{ Dependent variable } \\
\hline $\begin{array}{l}\text { Electronic Traceability } \\
\text { System (ETS) }\end{array}$ & $\begin{array}{l}=1 \text { if the firm have an Electronic traceability system, } 0 \\
\text { otherwise }\end{array}$ & ICT & \\
\hline \multicolumn{4}{|l|}{ Independent variables } \\
\hline \multicolumn{4}{|l|}{ Internal characteristics } \\
\hline Size & $\begin{array}{l}\text { Qualitative variable with } 4 \text { modalities: } \\
20 \text { to } 49 \text { employees } \\
50 \text { to } 249 \\
250 \text { to } 499 \\
\text { More than } 500\end{array}$ & EAE & $\begin{array}{l}\text { Reference } \\
\quad+ \\
+ \\
+ \\
+\end{array}$ \\
\hline Group & $=1$ if the firm is the subsidiary of a group, 0 if independent & LIFI & + \\
\hline Multi-unit & $=1$ if the firm have 2 or more establishments, 0 if single unit & EAE & + \\
\hline Brand image & Logarithm of total expenses in advertisement/total revenue & EAE & + \\
\hline \multicolumn{4}{|l|}{ Information systems } \\
\hline ERP & $\begin{array}{l}=1 \text { if the firm possess an Enterprise Resource Planning system, } \\
0 \text { otherwise }\end{array}$ & ICT & + \\
\hline DMS & $\begin{array}{l}=1 \text { if the firm possess a Document Management System, } 0 \\
\text { otherwise }\end{array}$ & $\mathrm{ICT}$ & + \\
\hline Workflow & $=1$ if the firm possess a Workflow System, 0 otherwise & ICT & + \\
\hline Data-warehouse & $=1$ if the firm possess a Data-warehouse, 0 otherwise & $\mathrm{ICT}$ & + \\
\hline EDI & $=1$ if the firm is equipped with an EDI, 0 otherwise & ICT & + \\
\hline Intranet & $=1$ if the firm is equipped with an Intranet, 0 otherwise & $\mathrm{ICT}$ & + \\
\hline Extranet & $=1$ if the firm is equipped with an Extranet, 0 otherwise & $\mathrm{ICT}$ & + \\
\hline \multicolumn{4}{|l|}{ Vertical relations } \\
\hline $\begin{array}{l}\text { Sales under a retailer's } \\
\text { brand }\end{array}$ & Logarithm of total sales under a retailer's brand/total revenue & EAE & + \\
\hline $\begin{array}{l}\text { Sales under another firm's } \\
\text { brand }\end{array}$ & $\begin{array}{l}\text { Logarithm of total sales under another firm's brand/total } \\
\text { revenue }\end{array}$ & EAE & + \\
\hline Capacity sub-contracting & $\begin{array}{l}\text { Logarithm of total expenses dedicated to sub-contracting of } \\
\text { capacity (when a firm possess the necessary competencies for a } \\
\text { certain activity, yet it chooses to occasionally hire another firm } \\
\text { to do it when its production capacity have been reached)/total } \\
\text { revenue }\end{array}$ & EAE & $?$ \\
\hline $\begin{array}{l}\text { Specialized sub- } \\
\text { contracting }\end{array}$ & $\begin{array}{l}\text { Logarithm of total expenses dedicated to specialized sub- } \\
\text { contracting (when a firm hires another firm having the } \\
\text { necessary competencies to do and activity followed by a set of } \\
\text { specification)/total revenue }\end{array}$ & EAE & + \\
\hline \multicolumn{4}{|c|}{ Characteristics of the environment } \\
\hline \multirow[t]{7}{*}{ Sector of activity } & Qualitative variable of 6 modalities: & EAE & \\
\hline & Meat sector & & Reference \\
\hline & Prepared fruit and vegetables & & - \\
\hline & Dairy products & & - \\
\hline & Processed animal feed & & - \\
\hline & Other food products & & - \\
\hline & Beverages & & - \\
\hline Market concentration & $\begin{array}{l}\text { Logarithm of the } \mathrm{C} 4 \text { concentration ratio : cumulated market } \\
\text { shares of the first four firms in the sector (at the NAF } 700 \text { level) }\end{array}$ & EAE & $?$ \\
\hline Exports $(E U)$ & $\begin{array}{l}\text { Logarithm of the exports rate to the European Union: EU } \\
\text { export/ total revenue of the firm }\end{array}$ & EAE & + \\
\hline Export (non EU) & $\begin{array}{l}\text { Logarithm of the exports rate outside the European Union: non- } \\
\text { EU export/ total revenue of the firm }\end{array}$ & EAE & + \\
\hline \multirow[t]{5}{*}{ Head office location } & Qualitative variable with 4 modalities: & EAE & \\
\hline & Urban area & & Reference \\
\hline & Peri-urban area & & - \\
\hline & Rural pole & & - \\
\hline & Rural isolated area & & - \\
\hline
\end{tabular}

Source: EAE, LIFI and ICT Survey (2002), French National Institutes of Statistics 


\begin{tabular}{|c|c|c|}
\hline Dependent variable: ETS & Coefficient & $(t)$ \\
\hline \multicolumn{3}{|l|}{ Internal characteristics } \\
\hline \multicolumn{3}{|l|}{ Structure } \\
\hline \multicolumn{3}{|l|}{ Size } \\
\hline From 20 to 49 & ref. & \\
\hline From 50 to 249 & $0.118^{*}$ & $(1.96)$ \\
\hline From 250 to 499 & $0.244^{*}$ & $(2.07)$ \\
\hline More than 500 & $0.468^{* *}$ & $(3.18)$ \\
\hline Group & $0.227^{* * *}$ & $(3.75)$ \\
\hline Multi-unit & -0.0177 & $(-0.31)$ \\
\hline Brand image & -0.0340 & $(-0.06)$ \\
\hline \multicolumn{3}{|l|}{ Information systems } \\
\hline ERP & $0.304^{* * *}$ & $(5.68)$ \\
\hline DMS & $0.380^{* * *}$ & $(4.17)$ \\
\hline Workflow & $0.274^{* *}$ & $(2.65)$ \\
\hline Data-warehouse & $0.223^{* *}$ & $(2.60)$ \\
\hline EDI & $0.329^{* * *}$ & $(5.60)$ \\
\hline Intranet & $0.400^{* * *}$ & $(6.38)$ \\
\hline Extranet & $0.265^{*}$ & $(2.52)$ \\
\hline \multicolumn{3}{|l|}{ Vertical relations } \\
\hline Sales under a retailer's brand & 0.00831 & $(0.04)$ \\
\hline Sales under another firms' brand & $1.419^{* * *}$ & $(4.35)$ \\
\hline Capacity Subcontracting & $-8.824^{* *}$ & $(-3.09)$ \\
\hline Specialized Subcontracting & $7.182^{* * *}$ & $(5.69)$ \\
\hline \multicolumn{3}{|c|}{ Characteristics of the environment } \\
\hline \multicolumn{3}{|c|}{ Sector of activity } \\
\hline Meat sector & ref. & \\
\hline Prepared fruit and vegetables & $-0.647^{* * *}$ & $(-4.71)$ \\
\hline Dairy products & $-0.359^{* * *}$ & $(-3.48)$ \\
\hline Processed animal feed & $-0.354^{* * *}$ & $(-3.29)$ \\
\hline Other food products & $-0.489^{* * *}$ & $(-6.24)$ \\
\hline Beverages & $-0.516^{* * *}$ & $(-4.59)$ \\
\hline Market concentration & 0.0232 & $(0.10)$ \\
\hline Exports (EU) & -0.0487 & $(-0.20)$ \\
\hline Exports (Non-EU) & $0.896^{*}$ & $(2.07)$ \\
\hline \multicolumn{3}{|l|}{ Main office location } \\
\hline Urban area & ref. & \\
\hline Peri-urban area & $0.182^{* *}$ & $(2.64)$ \\
\hline Rural pole & $0.448^{* * *}$ & $(5.62)$ \\
\hline Rural isolated area & $-0.254^{* * *}$ & $(-3.36)$ \\
\hline Constant & $-0.854^{* * *}$ & $(-10.43)$ \\
\hline Log-likelihood & -1593.887 & \\
\hline$\chi_{(28)}^{2}$ & $669.99^{* * *}$ & \\
\hline Observations & 871 & \\
\hline (Weighted data) & $(2821)$ & \\
\hline Pseudo $R^{2}$ (McFadden's) & 0.174 & \\
\hline$B I C$ (Schwarz's criterion) & 3418.2 & \\
\hline$\%$ of correct predictions & 43.20 & \\
\hline
\end{tabular}

$t$ statistics in parentheses.

Statistical significance: ${ }^{*} p<0.05,{ }^{* *} p<0.01,{ }^{* * *} p<0.001$

Source: EAE, LIFI and ICT Survey (2002), French National Institutes of Statistics 
Table 4: Summary of hypothesis and results

\begin{tabular}{|c|c|c|c|}
\hline \multicolumn{4}{|c|}{ Dependent variable: ETS adoption } \\
\hline Number & Hypothesis & $\begin{array}{c}\text { Expected } \\
\text { Relationship }\end{array}$ & Result \\
\hline Hyp. 1 & Firm size & Positive & Accepted \\
\hline \multirow[t]{2}{*}{ Hyp. 2} & Firm's belonging to a group & Positive & Accepted \\
\hline & Firm's with multiple units & Positive & No evidence \\
\hline Hyp. 3 & Importance of brand image & Positive & No evidence \\
\hline Hyp. 4 & Use of e-business applications & Positive & Accepted \\
\hline Hyp. 5 & $\begin{array}{l}\text { Use of contracts/specifications with customers and } \\
\text { suppliers }\end{array}$ & Positive & Accepted \\
\hline Hyp. 6 & High adoption in the firm's sector of activity & Positive & Accepted \\
\hline Hyp. 7 & Internationalization of the firm's activity & Positive & Accepted \\
\hline Hyp. 8 & Location of the firm in urban areas & Positive & Rejected \\
\hline
\end{tabular}


Table A1: Correlation matrix of the independent variables

\begin{tabular}{|c|c|c|c|c|c|c|c|c|c|c|c|c|c|c|c|}
\hline & & 1 & 2 & 3 & 4 & 5 & 6 & & 8 & 9 & 10 & 11 & 12 & 13 & 14 \\
\hline 1 & From 50 to 249 & & & & & & & & & & & & & & \\
\hline 2 & From 250 to 499 & $-0.372 * * *$ & & & & & & & & & & & & & \\
\hline 3 & More than 500 & $-0.343^{* * *}$ & $-0.224 * * *$ & & & & & & & & & & & & \\
\hline 4 & Group & -0.029 & $0.213^{* * *}$ & $0.247 * * *$ & & & & & & & & & & & \\
\hline 5 & Multi-unit & $-0.106^{* *}$ & 0.061 & $0.347 * * *$ & $0.191 * * *$ & & & & & & & & & & \\
\hline 6 & Brand image & $-0.145^{* * *}$ & 0.064 & $0.34^{* * *}$ & $0.16^{* * *}$ & $0.175^{* * *}$ & & & & & & & & & \\
\hline 7 & ERP & -0.007 & $0.075^{*}$ & 0.024 & $0.114^{* * *}$ & -0.008 & $0.169^{* * *}$ & & & & & & & & \\
\hline 8 & DMS & $-0.07^{*}$ & $0.071^{*}$ & $0.202 * * *$ & $0.142^{* * *}$ & $0.117 * * *$ & 0.085 & 0.063 & & & & & & & \\
\hline 9 & Workflow & $-0.106^{* *}$ & $0.088^{* *}$ & $0.291^{* * *}$ & $0.229 * * *$ & $0.169^{* * *}$ & $0.2 * * *$ & 0.06 & $0.362^{* * *}$ & & & & & & \\
\hline 10 & Data-warehouse & $-0.122 * * *$ & $0.094^{* *}$ & $0.398^{* * *}$ & $0.298^{* * *}$ & $0.23 * * *$ & $0.279^{* * *}$ & $0.093 * *$ & $0.285^{* * *}$ & $0.378^{* * *}$ & & & & & \\
\hline 11 & EDI & -0.023 & $0.154^{* * *}$ & $0.232 * * *$ & $0.163^{* * *}$ & $0.153^{* * *}$ & $0.252 * * *$ & $0.135^{* * *}$ & $0.12 * * *$ & $0.18^{* * *}$ & $0.263^{* * *}$ & & & & \\
\hline 12 & Intranet & $-0.076^{* *}$ & $0.215^{* * *}$ & $0.308^{* * *}$ & $0.365^{* * *}$ & $0.224 * * *$ & $0.168^{* * *}$ & 0.061 & $0.27^{* * *}$ & $0.349 * * *$ & $0.355^{* * *}$ & $0.269^{* * *}$ & & & \\
\hline 13 & Extranet & $-0.079^{* *}$ & 0.051 & $0.209^{* * *}$ & $0.151^{* * *}$ & $0.151^{* * *}$ & $0.096^{* *}$ & 0.032 & $0.171^{* * *}$ & $0.196^{* * *}$ & $0.233^{* * *}$ & $0.131^{* * *}$ & $0.248^{* * *}$ & & \\
\hline 14 & Retailer's brand & -0.019 & $0.074^{*}$ & $0.084 *$ & $0.111^{* * *}$ & -0.022 & 0.04 & 0.027 & -0.004 & 0.03 & 0.036 & $0.154 * * *$ & $0.069^{*}$ & 0.053 & \\
\hline 15 & Other brand & 0.044 & $0.091 * *$ & -0.061 & 0.022 & -0.033 & -0.046 & -0.004 & 0.049 & -0.003 & -0.005 & 0.035 & 0.022 & 0.002 & $0.229^{* * *}$ \\
\hline 16 & Cap. Subcontract & -0.054 & $0.074^{*}$ & 0.021 & 0.062 & -0.033 & 0.006 & -0.002 & 0.049 & 0.043 & 0.035 & 0.054 & 0.058 & 0.033 & 0.021 \\
\hline 17 & Spec. Subcontract & -0.029 & -0.018 & 0.021 & 0.055 & 0.035 & 0.062 & -0.014 & 0.001 & 0.013 & 0.023 & 0.028 & 0.041 & -0.025 & -0.007 \\
\hline 18 & Prepared F\&V & 0.024 & 0.004 & -0.02 & -0.009 & -0.051 & -0.028 & 0.022 & -0.026 & 0.011 & -0.043 & $0.079^{*}$ & -0.012 & -0.063 & $0.077^{*}$ \\
\hline 19 & Dairy products & -0.062 & 0.056 & 0.052 & 0.016 & -0.024 & 0.021 & $-0.086^{*}$ & 0.03 & $0.089^{* *}$ & 0.009 & 0.046 & $0.106^{* *}$ & 0.016 & $0.091^{* *}$ \\
\hline 20 & Feed & 0.055 & -0.056 & -0.065 & 0.044 & 0.033 & -0.114 & -0.035 & 0.024 & -0.019 & 0.01 & $-0.124^{* * *}$ & -0.004 & -0.018 & $-0.077^{*}$ \\
\hline 21 & Other & 0.022 & -0.061 & -0.013 & 0.014 & 0.043 & $0.121^{* * *}$ & $0.138^{* * *}$ & -0.026 & 0.035 & -0.032 & -0.041 & -0.038 & -0.009 & $0.067^{*}$ \\
\hline 22 & Beverages & 0.03 & -0.031 & -0.05 & 0.035 & $0.083^{*}$ & $0.074^{*}$ & -0.009 & 0.036 & 0.046 & $0.093^{* *}$ & 0.065 & 0.06 & $0.134 * * *$ & -0.044 \\
\hline 23 & Market conce. & 0.004 & -0.052 & $0.129^{* * *}$ & $0.092 * *$ & $0.127^{* * *}$ & $0.211^{* * *}$ & $0.085^{*}$ & 0.059 & $0.188^{* * *}$ & $0.086^{*}$ & $0.106^{* *}$ & $0.096^{* *}$ & $0.078^{*}$ & $0.136^{* * *}$ \\
\hline 24 & Exports (EU) & -0.063 & 0.049 & $0.15^{* * *}$ & 0.06 & 0.028 & -0.001 & $0.068^{*}$ & $0.073^{*}$ & $0.109^{* *}$ & $0.093 * *$ & 0.063 & $0.141^{* * *}$ & 0.031 & 0.065 \\
\hline 25 & Exports (Non-EU) & -0.008 & 0.014 & 0.052 & $0.097^{* *}$ & 0.063 & 0.053 & $0.073 *$ & 0.062 & $0.115^{* *}$ & 0.065 & 0.01 & $0.084^{*}$ & $0.149^{* * *}$ & -0.063 \\
\hline 26 & Peri-urban area & 0.032 & -0.005 & $-0.087^{*}$ & -0.035 & -0.06 & $-0.076^{*}$ & -0.007 & $-0.071^{*}$ & -0.044 & $-0.079^{*}$ & -0.007 & 0.006 & -0.055 & -0.039 \\
\hline 27 & Rural pole & -0.017 & 0.001 & 0 & 0.063 & $-0.089 * *$ & -0.042 & -0.008 & 0.007 & 0.042 & 0.009 & -0.044 & -0.023 & 0.031 & -0.022 \\
\hline 27 & Rural isolated & 0.043 & 0.006 & $-0.074^{*}$ & $-0.088^{* *}$ & -0.015 & $-0.112 * *$ & $-0.07^{*}$ & -0.058 & $-0.076^{*}$ & $-0.072 *$ & -0.054 & -0.041 & -0.038 & 0.049 \\
\hline
\end{tabular}
${ }^{*} p<0.05,{ }^{* *} p<0.01,{ }^{* * *} p<0.001$

\begin{tabular}{|c|c|c|c|c|c|c|c|c|c|c|c|c|c|c|c|}
\hline & & 15 & 16 & & 17 & 19 & 20 & 21 & 22 & 23 & 24 & & 25 & 27 & 28 \\
\hline 16 & Cap. Subcontract & -0.024 & & & & & & & & & & & & & \\
\hline 17 & Spec. Subcontract & -0.023 & 0.011 & & & & & & & & & & & & \\
\hline 18 & Prepared F\&V & 0.025 & -0.021 & $0.08^{*}$ & & & & & & & & & & & \\
\hline 19 & Dairy products & 0.058 & $0.123^{* * *}$ & -0.027 & $-0.109^{* * *}$ & & & & & & & & & & \\
\hline 20 & Feed & -0.053 & -0.033 & 0.04 & $-0.084^{*}$ & $-0.097^{* *}$ & & & & & & & & & \\
\hline 21 & Other & -0.013 & -0.05 & -0.049 & $-0.215 * * *$ & $-0.248^{* * *}$ & $-0.192 * * *$ & & & & & & & & \\
\hline 22 & Beverages & 0.008 & 0.006 & 0.005 & $-0.107 * *$ & $-0.123^{* * *}$ & $-0.095 * *$ & $-0.243 * * *$ & & & & & & & \\
\hline 23 & Market conce. & 0.005 & -0.01 & -0.007 & $0.207^{* * *}$ & $0.091^{* *}$ & $-0.17^{* * *}$ & $0.265^{* * *}$ & $0.26^{* * *}$ & & & & & & \\
\hline 24 & Exports (EU) & 0.03 & 0.041 & $0.079 *$ & $0.081 *$ & 0.002 & -0.066 & 0.022 & $0.158^{* * *}$ & $0.204^{* * *}$ & & & & & \\
\hline 25 & Exports (Non-EU) & -0.063 & 0.015 & 0.028 & -0.001 & -0.023 & -0.022 & -0.045 & $0.291 * * *$ & $0.169^{* * *}$ & $0.28 * * *$ & & & & \\
\hline 26 & Peri-urban area & 0.033 & 0.025 & -0.045 & -0.003 & 0.02 & -0.039 & -0.015 & 0.007 & -0.031 & -0.023 & -0.005 & & & \\
\hline 27 & Rural pole & 0.001 & -0.013 & -0.032 & 0.011 & -0.011 & -0.003 & -0.053 & -0.018 & -0.066 & 0.004 & 0.007 & $-0.2 * * *$ & & \\
\hline 28 & Rural isolated & $0.083^{*}$ & -0.004 & 0.016 & 0.045 & $0.115^{* * *}$ & 0.056 & $-0.136 * * *$ & -0.06 & $-0.095^{* *}$ & -0.028 & -0.066 & $-0.24 * * *$ & $-0.187 * * *$ & \\
\hline
\end{tabular}

$$
{ }^{*} p<0.05,{ }^{* *} p<0.01,{ }^{* * *} p<0.001
$$

